\title{
Artikel
}

\section{Controleren van gemeentelijke samenwerking}

\section{Een blik op interbestuurlijk toezicht vanuit het perspectief van gemeenteraden}

\author{
Klaartje Peters*
}

Gemeenteraden worstelen met hun controlerende taak, zeker ten aanzien van de grote regionale samenwerkingsverbanden zoals de Veiligheidsregio, de GGD en de Omgevingsdienst. De kwaliteit van de informatievoorziening over prestaties van die verbanden is een belangrijk knelpunt. Bij nadere beschouwing blijkt dat Rijksinspecties en de provincies in hun rol als interbestuurlijk toezichthouder regelmatig onderzoek doen naar gemeenten en hun samenwerkingsverbanden dat voor gemeenteraden uiterst bruikbaar is. Gemeenteraden lijken daar weinig gebruik van te maken, deels doordat zij niet worden geinformeerd over de onderzoeken en de resultaten ervan. Dat moet veranderen: er moet bij toezichthouders meer oog komen voor het belang van gemeenteraden als eerste controleur van het gemeentebestuur.

\section{Inleiding}

De afgelopen jaren hebben grote en ingrijpende veranderingen plaatsgevonden in het Nederlandse lokaal bestuur. In termen van taken en publieke uitgaven heeft

* Prof. dr. K. Peters is zelfstandig onderzoeker, rekenkamerlid en bijzonder hoogleraar Lokaal en regionaal bestuur aan de Universiteit Maastricht. De auteur bedankt allen die commentaar hebben geleverd op een eerdere versie van dit artikel, in het bijzonder Tineke van de Biggelaar, Rob de Greef, Solke Munneke, Rolf Willemse en Heinrich Winter. het lokaal bestuur aanzienlijk aan belang gewonnen. ${ }^{1}$ De omvang en de impact van de naar gemeenten gedecentraliseerde taken in met name het sociale domein, zoals de jeugdzorg en maatschappelijke ondersteuning, is groot. De hervorming van de verzorgingsstaat vindt feitelijk plaats in het lokaal bestuur, een ontwikkeling die door directeur Putters van het Sociaal en Cultureel Planbureau (SCP) is geduid als 'van verzorgingsstaat naar verzorgingsstad'. ${ }^{2}$ In het ruimtelijk domein zijn de aanstaande veranderingen door onder meer de geplande invoering van de Omgevingswet in 2021 minstens zo ingrijpend.

Met de recente groei van taken van gemeenten, vooral in het sociaal domein, is de behoefte aan inzicht in prestaties en besteding van middelen door gemeenten navenant toegenomen. Wie controleert eigenlijk het gemeentebestuur? Staatsrechtelijk gezien is het uitgangspunt dat de gemeenteraad als hoogste orgaan van de gemeente dat doet. Met name voor de nieuwe taken in het sociaal domein is die lokale autonomie de afgelopen jaren voor alle betrokkenen een worsteling gebleken. In politiek Den Haag wil de Tweede Kamer toch graag meekijken met de manier waarop de gedecentraliseerde taken door gemeenten worden uitgevoerd. ${ }^{3}$ Dat is niet nieuw overigens: het is een bekend Haags mechanisme dat Kamerleden zich niet altijd veel gelegen laten liggen

1. M.A. Allers en B. Steiner, Gemeenten in perspectief 2014-2018, Groningen: Centrum voor Onderzoek van de Economie van Lagere Overheden 2015.

2. K. Putters, Het smalle pad van verzorgingsstaat naar verzorgingsstad, lezing De Balie, 23 mei 2013.

3. Raad voor het openbaar bestuur, Ondertussen in Den Haag. Over de invloed van de decentralisaties op het functioneren van de rijksoverheid, Den Haag 2019. 
aan de verhoudingen in de gedecentraliseerde eenheidsstaat en de eigen verantwoordelijkheid van gemeenten. In recente rapporten over de decentralisaties in het sociaal domein vragen de Raad van State, de Algemene Rekenkamer en de Raad voor het openbaar bestuur niet voor niets nadrukkelijk aandacht voor het respecteren van de gemeentelijke beleidsvrijheid, de 'spelregels bij gedecentraliseerde taken' en de sluipende en impliciete 'recentralisatietendens'. ${ }^{4}$ Als Kamerleden vragen stellen aan de regering over de taakuitvoering door gemeenten, hoort het antwoord van de minister in principe te zijn: 'Daarvoor moet u niet bij mij zijn, daar gaat de gemeente over'. 5 Kamerleden, de media en landelijke belangenorganisaties vinden dat antwoord echter niet altijd bevredigend.

Maar ook voor de spelers op lokaal niveau zijn de veranderingen ingrijpend. Voor gemeenteraden is, door de overheveling van taken naar gemeenten, hun controlerende taak de afgelopen jaren aanzienlijk verzwaard. Die controlerende taak wordt gecompliceerd door de groeiende regionale samenwerking. De gedecentraliseerde taken zijn zodanig omvangrijk en complex dat gemeenten ervoor kiezen, en deels ook wettelijk worden verplicht, om deze veelal in samenwerking met andere gemeenten in de regio uit te voeren. Denters schaart deze ontwikkeling onder een bredere trend van 'verplaatsing van de politiek', die in het lokaal bestuur tot verandering en uitholling van bestaande controle- en verantwoordingsrelaties en arrangementen heeft geleid. ${ }^{6}$ De omvang én groei van het aantal regionale samenwerkingsverbanden leiden tot grotere afstand tussen raadsleden en de besluitvorming en uitvoering van de in die verbanden belegde taken, zowel objectief als subjectief. Dit is een ontwikkeling die overal in het land speelt, en die in diverse recente rapporten en handreikingen is gesignaleerd. $^{7}$ Dit heeft gevolgen voor de controle(mogelijkheden) door raadsleden. Los van de meer principiële vraag of de groeiende regionalisering wenselijk is vanuit democratisch oogpunt, zijn de meeste deskundigen het erover eens dat versterking van de rol en

4. Algemene Rekenkamer, Wegwijs in het sociaal domein. Advies ter verbetering van de informatievoorziening door de regering aan de Tweede Kamer met betrekking tot de Participatiewet, de Jeugdwet en de Wmo 2015, Den Haag 2018; Raad van State, En nu verder! Vierde periodieke beschouwing over interbestuurlijke verhoudingen na de decentralisaties in het sociale en fysieke domein, Den Haag 2016; Raad voor het openbaar bestuur, Ondertussen in Den Haag. Over de invloed van de decentralisaties op het functioneren van de rijksoverheid, Den Haag 2019.

5. In de Haagse praktijk doen bewindslieden dit niet altijd op die manier, zoals bijvoorbeeld mooi is beschreven door Boogaard en Van Emmerik in hun bijdrage aan de eerste evaluatie van de nieuwe Jeugdwet over de feitelijke invulling van de stelselverantwoordelijkheid in het jeugddomein: G. Boogaard en M.L. van Emmerik, 'Decentralisatie van politieke verantwoordelijkheid. Evaluatie van de stelselverantwoordelijkheid onder de nieuwe Jeugdwet', in: R.D. Friele e.a., Eerste evaluatie Jeugdwet, Den Haag: ZonMw 2018, p. 134-165.

6. B. Denters, Controle en verantwoording in een veranderend lokaal bestuur (Essay voor de Nederlandse vereniging voor raadsleden), Enschede: Universiteit Twente 2015, p. 2-4.

7. Zie bijvoorbeeld: Raad voor het openbaar bestuur, Wisselwerking. Naar een betere wisselwerking tussen gemeenteraden en de bovengemeentelijke samenwerking, Den Haag 2015. positie van de gemeenteraad in dit opzicht mogelijk is, maar wel een forse inspanning van alle betrokken actoren vereist in termen van aandacht, attitude en scholing, en zeker ook een betere informatievoorziening en een cultuur van openheid en actieve verantwoording. ${ }^{8}$ Het recent in consultatie gegane wetsvoorstel democratisering samenwerkingsverbanden ${ }^{9}$ biedt in dit opzicht enkele concrete verbeteringen.

Goed beschouwd is de gemeenteraad echter niet de enige die het lokaal bestuur controleert. De provincies zijn toezichthouder voor alle medebewindstaken die bij wet aan de gemeenten zijn opgedragen, met uitzondering van enkele belangrijke uitzonderingen waar het Rijk de rol van toezichthouder vervult. ${ }^{10}$ Dat betekent dat de gemeenten ook door de provincie en de rijksinspecties worden gecontroleerd, op een diverse verzameling van taakgebieden. Gemeenteraadsleden zijn zich hier lang niet altijd van bewust. Veel raadsleden weten dat de provincie financieel toezicht uitoefent op gemeenten ${ }^{11}$ - in gemeenten met financiële problemen kent iedereen het bestaan van het zogenoemde preventief financieel toezicht -, maar dat geldt zeker niet voor alle taakgebieden waarop een hogere overheid meekijkt. Dit roept de vraag op of gemeenteraden bij de vervulling van hun controlerende rol gebruikmaken van de informatie en de bevindingen van de provinciale toezichthouder en de rijksinspecties, en hoe dat gebruik zou kunnen worden bevorderd. Dat is de probleemstelling van dit artikel. Uit pragmatische overwegingen focus ik daarbij in eerste instantie op het deel van het raadswerk dat gemeenteraden de afgelopen jaren de meeste hoofdbrekens heeft gekost: de regionale samenwerkingsverbanden waar alle Nederlandse gemeenten deel van uitmaken.

\section{Controle door gemeenteraden: een moeizaam verhaal}

Terwijl gemeentebesturen druk bezig zijn met de nieuwe gemeentelijke taken en de grote uitdagingen in het lokaal bestuur, lijkt de representatieve democratie op lokaal niveau de laatste jaren in problemen te verkeren. Recente signalen, zoals het steeds grotere verloop onder raadsleden en acute moeilijkheden ook voor gevestigde politieke partijen om kandidaten voor de komende gemeenteraadsverkiezingen te vinden, duiden op dieperliggende problemen. Die problemen worden geduid in gezaghebbende rapporten van adviesraden en

8. Raad voor het openbaar bestuur 2015 .

9. www.internetconsultatie.nl/ democratischelegitimatiegemeenschappelijkeregelingen.

10. Taken opgenomen in Bijlage 1 van de Gemeentewet; de grondslag hiervoor is te vinden in art. 124b Gemeentewet. Daarnaast heeft de rijksoverheid ook nog een algemene toezichthoudende taak via het vernietigingsrecht.

11. Zie bijvoorbeeld H.B. Winter, S.A.J. Munneke, J.B. Geertsema, E. Krol, J. de Ridder, N. Struiksma en C. Veen, Evaluatie van de Wet revitalisering generiek toezicht, Groningen: Pro Facto 2017, p. 65. 
onderzoekscommissies. ${ }^{12}$ Het beeld dat daaruit oprijst, is dat van volksvertegenwoordigers die worstelen met hun rol en een gebrek aan invloed op het bestuur en de ontwikkelingen op (boven)lokaal niveau. De gemeenteraad is volgens de commissie-Ollongren 'het kruispunt van de democratie', maar dreigt daar overreden te worden, zou je met enig gevoel voor drama kunnen zeggen. De commissie-Van de Donk, die zich enkele jaren geleden boog over de vraag 'of de inrichting van ons bestuurlijke systeem effectief genoeg is om de huidige en toekomstige maatschappelijke opgaven aan te kunnen', stelt dat 'het moeilijk [is] om die vraag met ja te beantwoorden. Er is zelfs reden tot zorg, vooral waar het gaat om het politiek en democratisch functioneren van het lokaal bestuur'. ${ }^{13}$ Sommige politicologen wijzen erop dat burgers relatief veel vertrouwen hebben in politieke instituties op lokaal niveau en tevreden zijn over de prestaties van de gemeentelijke overheid, ${ }^{14}$ maar ook zij moeten erkennen dat er reden is voor bezorgdheid, ${ }^{15}$ niet in het minst vanwege het almaar groeiende aantal intergemeentelijke samenwerkingsverbanden. ${ }^{16}$

De zorg over de lokale democratie mag dan breed worden gedeeld, de genoemde rapporten baseren zich daarbij niet op empirische gegevens over de wijze waarop gemeenteraden in de praktijk hun kaderstellende en controlerende taak vervullen. ${ }^{17}$ Dat kan ook niet, want er zijn nauwelijks gegevens over beschikbaar. Het weinige beschikbare onderzoek ${ }^{18}$ wijst op onderbenutting van beschikbare instrumenten door gemeenteraden en bezorgdheid over de wijze waarop gemeenteraden door

12. Raad voor het Openbaar Bestuur 2015; Raad voor het openbaar bestuur, 15,9 uur. De verbindende rol van het raadslid in een vitale democratie, Den Haag 2016; Commissie-Van de Donk (Commissie toekomstgericht lokaal bestuur), Op weg naar meervoudige democratie, Den Haag: VNG 2016; Commissie-Ollongren (VNG Denktank), Maatwerkdemocratie. Naar een krachtiger, trefzekere gemeenteraad 2020 als kruispunt in de lokale democratie, Jaarbericht 2016, Den Haag: VNG 2016; Studiegroep openbaar bestuur, Maak verschil. Krachtig inspelen op regionaal-economische opgaven, Den Haag: ministerie van BZK 2016.

13. Commissie-Van de Donk 2016, p. 4.

14. T. van der Meer en H. van der Kolk (red.), Democratie dichterbij. Lokaal kiezersonderzoek 2016, Den Haag: ministerie van BZK 2016.

15. T. van der Meer, 'Slotbeschouwing: geen levende lokale democratie zonder scepsis', Bestuurswetenschappen 2017, nr. 3, p. 84-87; H. van der Kolk, 'Inleiding: Beter zicht op de Nederlandse lokale democratie', Bestuurswetenschappen 2017, nr. 3, p. 5-10.

16. B. Denters, P-J. Klok en A. Kranenburg, 'Greep op het ongrijpbare? Een onderzoek naar nieuwe vormen van controle en verantwoording in een samenwerkend lokaal bestuur', Bestuurswetenschappen 2017, nr. 4, p. 25-44; M. Boogers, 'Democratische sturing, controle en verantwoording van de regio', Bestuurswetenschappen 2017, nr. 3, p. 3-4.

17. Ik laat hier buiten beschouwing de derde taak of rol die gemeenteraden sinds de dualisering is toebedeeld: de volksvertegenwoordigende. Overigens is het in mijn ogen een vergissing geweest om in die tijd in de communicatie naar raadsleden (door de 'Vernieuwingsimpuls') het zijn van volksvertegenwoordiger als een specifieke rol te benoemen; dat heeft tot veel verwarring geleid.

18. B\&A Groep, Staat van het Dualisme, in opdracht van het ministerie van BZK, Den Haag 2008; J.W.M.M.J. Hessels, Raad zonder Raadgevers. Ambtelijke bijstand en fractieondersteuning na invoering van de Wet dualisering gemeentebestuur (diss. Nijmegen), Deventer: Wolters Kluwer 2018; K. Peters en P. Castenmiller, Om de controle door de raad. Een onderzoek naar de toepassing van het raadsinstrumentarium voor controle en kaderstelling in de gemeentelijke praktijk, in opdracht van het ministerie van BZK, Den Haag 2019. hun colleges worden geïnformeerd. Goede en onafhankelijke informatievoorziening is daarbij altijd een bottle neck. Gemeenteraden beschikken over een - vaak zeer bescheiden opgezette - rekenkamer en doen heel af en toe zelf raadsonderzoek of een raadsenquête, maar veel meer instrumenten worden er in dit opzicht niet ingezet. De laatste jaren krijgt het thema van controle door de gemeenteraad wat meer aandacht van bestuurskundigen. ${ }^{19}$ In deze publicaties ligt de nadruk vooral op het versterken van de controlerende taak van de raad, onder meer door het in beeld brengen van vernieuwende manieren van controle en verantwoording, al dan niet op initiatief van, of in samenwerking met burgers en andere (maatschappelijke) partijen. Duidelijk blijkt dat raadsleden het moeilijk hebben met hun controlerende taak. Dat het niet goed gaat, wordt wel gesuggereerd maar blijft enigszins impliciet.

Voor één aspect van het controlerende werk van gemeenteraden in het bijzonder is wel veel aandacht geweest de afgelopen jaren. Een steeds terugkerende constatering in enquêtes onder raadsleden en landelijke en lokale onderzoeksrapporten is dat raadsleden uiterst ontevreden zijn over de controlemogelijkheden die zij hebben ten aanzien van het groeiend aantal regionale samenwerkingsverbanden. ${ }^{20}$ Empirisch onderzoek, met name door lokale rekenkamers, ${ }^{21}$ laat zien dat de indirecte sturings- en controlerelatie en de groeiende complexiteit het voor veel raadsleden moeilijk maken om voldoende controle uit te oefenen op de taken die op regionaal niveau worden uitgevoerd. Het is niet overdreven om te stellen dat bijna elke zichzelf respecterende gemeentelijke rekenkamer(commissie) de afgelopen jaren over dit onderwerp een rapport of een handreiking voor de gemeenteraad heeft gepubliceerd. Uit al die documenten blijkt dat raadsleden in het bijzonder worstelen met de gebrekkige informatievoorziening over de prestaties en effectiviteit van met name de grote, wettelijk verplichte gemeenschappelijke regelingen, zoals onder meer de Veiligheidsregio, de Omgevingsdienst en de Gemeentelijke Gezondheidsdienst (GGD).

19. Denters, Klok en Kranenburg 2017, p. 25-44; J. Schram, M. van Twist en M. van der Steen, Raad en hulptroepen. Hefbomen ter versterking van de controlerende taak van de gemeenteraad, Den Haag: NSOB 2017; B. Denters, 'Controle en verantwoording in een veranderend lokaal bestuur', Bestuurswetenschappen 2016, nr. 1, p. 37-54.

20. Zie onder meer: M.J.G.J.A. Boogers en G.H. Reussing, Decentralisatie, schaalvergroting en lokale democratie. Samenvattend onderzoek naar gevolgen voor rollen en posities van lokale bestuurders en naar gevolgen voor bestuurskracht en democratie, Enschede: Universiteit Twente 2018; Nederlandse Vereniging voor Raadsleden, Raad \& Regionale Samenwerking 2017. Landelijk Raadsledenonderzoek over grip en controle op regionale samenwerking, gemeenschappelijke taken en herindeling, Den Haag 2017; M.J.G.J.A. Boogers, P.J. Klok, S.A.H. Denters en M.P.T. Sanders, Effecten van regionaal bestuur voor gemeenten. Bestuursstructuur, samenwerkingsrelaties, democratische kwaliteit en bestuurlijke effectiviteit, Enschede: Universiteit Twente 2016; Raad voor het openbaar bestuur 2015; Daadkracht, Nationaal Raadsleden Onderzoek 2014 en Nationaal Raadsleden Onderzoek 2017, Nijmegen.

21. Enkele recente voorbeelden zijn: Rekenkamer(commissie)s Rijk van Nijmegen, Grip krijgen op Veilig Thuis, 2017; Rekenkamer Den Haag, Moeite met afstand, 2016; Rekenkamer Breda, Verbonden partijen en de rol van de raad. Een onderzoek naar de informatievoorziening, sturing en beheersing ten aanzien van verbonden partijen in Breda, 2015. 
De grote afstand tussen gemeenteraden en deze organisaties en het 'getrapte' en gemankeerde stelsel van controle en verantwoording dat we in het leven hebben geroepen (in de Wet gemeenschappelijke regelingen (Wgr), ${ }^{22}$ maakt het voor raadsleden bijzonder moeilijk hun kaderstellende en controlerende taak goed te vervullen.

\section{Veilig Thuis in de regio Rijk van Nijmegen: een casus}

In 2018 publiceren de gezamenlijke rekenkamer(commissie)s van de gemeenten in Rijk van Nijmegen ${ }^{23}$ een onderzoek naar de wijze waarop de gemeenteraden van hun gemeenten hun kaderstellende en controlerende rol ten aanzien van Veilig Thuis hebben ingevuld.

\section{Veilig Thuis: de start}

Met de decentralisaties in het sociaal domein in 2015 zijn gemeenten onder meer verantwoordelijk geworden voor Veilig Thuis, het nieuwe advies- en meldpunt voor huiselijk geweld en kindermishandeling. $\mathrm{Zij}$ werken daarbij verplicht samen op regionaal niveau. In de regio Gelderland Zuid, een van de 26 regio's die zijn gevormd, hebben de gemeenten Veilig Thuis ondergebracht bij de GGD. De GGD is een gemeenschappelijke regeling ${ }^{24}$ van zestien gemeenten, verdeeld over de regio's Rijk van Nijmegen en Rivierenland. De voorbereiding in 2014 wordt sterk getekend door onduidelijkheid en onzekerheid bij gemeenten over de overheveling van taken en budgetten in het sociaal domein.

\section{Veilig Thuis Gelderland Zuid: problemen}

Al vanaf de start in januari 2015 is duidelijk dat het niet goed loopt bij Veilig Thuis Gelderland Zuid (VTGZ). Het aantal meldingen is groter dan verwacht, de werkdruk bij de medewerkers is hoog en de nieuwe manier van werken voor de medewerkers van de drie samengevoegde organisaties $^{25}$ komt niet van de grond. Pas in juni 2015 worden de problemen voor het eerst geagendeerd in het Dagelijks bestuur (DB) en

22. Het is van belang om hierbij aan te tekenen dat gemeenteraden in het geval van gemeenschappelijke regelingen juridisch gezien een beperktere controlerende rol hebben dan in het geval van 'gewone' gemeentelijke taken. In de Wet gemeenschappelijke regelingen is bepaald dat gemeenteraden hun lid van het Algemeen bestuur alleen ter verantwoording kunnen roepen voor het door hem in dat bestuur gevoerde beleid.

23. Het betreft de rekenkamer(commissie)s van de gemeenten Berg en Dal, Beuningen, Heumen, Nijmegen, West Maas en Waal en Wijchen. De gemeente Druten, die ook deel uitmaakt van de regio, heeft in deze periode geen rekenkamer.

24. Het betreft een collegeregeling, met een Algemeen bestuur bestaande uit wethouders van de deelnemende gemeenten.

25. Het betreft het Advies- en Meldpunt Kindermishandeling (van Bureau Jeugdzorg), het burgermeldpunt (van Moviera) dat de taken van het Steunpunt Huiselijk Geweld uitvoerde, samen met het Meldpunt Bijzondere Zorg (van de GGD Gelderland Zuid).
Algemeen bestuur (AB) van de GGD. Er wordt dan nog van uitgegaan dat het om tijdelijke opstartproblemen gaat. De gemeenteraden worden in deze periode niet geïformeerd over de problemen bij Veilig Thuis.

In de tweede helft van 2015 voeren de Inspectie Jeugdzorg en de Inspectie voor de Gezondheidszorg samen de eerste stap uit van het toezicht bij alle 26 Veilig Thuis-organisaties. Binnen het jeugdstelsel zijn de beide inspecties samen met de Inspectie Veiligheid en Justitie verantwoordelijk voor het landelijk toezicht op de kwaliteit van de jeugdhulp, de jeugdbescherming en -reclassering en op de naleving van de wetgeving. Het toezicht op Veilig Thuis richt zich op basiseisen op het gebied van randvoorwaarden, veiligheid en organisatie. Uit het onderzoek blijkt dat VTGZ op 16 van de 24 toetsingscriteria een onvoldoende scoort. Daarop wordt het toezicht op VTGZ geintensiveerd. Hierover worden de gemeenteraden door hun wethouders geïnformeerd.

In de daaropvolgende maanden stellen Veilig Thuis en de GGD in opdracht van de inspecties een verbeterplan op, dat in het voorjaar van 2016 tot resultaat moet leiden. Hiervoor is meer geld nodig dan eerder voorzien en dus wordt een begrotingswijziging voor 2016 in gang gezet. Eind 2015/begin 2016 worden de gemeenteraden geinformeerd over het verbeterplan en gevraagd in te stemmen met de begrotingswijziging. Door middel van twee voortgangsaudits worden het $\mathrm{AB}$ (en in het verlengde daarvan de gemeenteraden) op de hoogte gesteld van de stappen die de organisatie zet om zo spoedig mogelijk te voldoen aan de toetsingscriteria van de inspecties.

\section{Verscherpt toezicht}

In april 2016 ontvangen enkele Nijmeegse raadsfracties, de inspecties en de regionale krant $D e$ Gelderlander een anonieme brief over de problemen met (deels verborgen) wachtlijsten en de ongestructureerde werkwijze bij Veilig Thuis. Als de inspecties naar aanleiding van de brief een onaangekondigd bezoek brengen aan VTGZ, wordt vastgesteld dat de organisatie 'een vertekend beeld over de wachtlijst aan de inspecties heeft gegeven'. ${ }^{26}$ Het gaat daarbij ook om een groot aantal cases waarvan de eerste beoordeling nog moet plaatsvinden. Daarop besluiten de inspecties eind april om VTGZ onder verscherpt toezicht te plaatsen.

\section{6: het vervolg}

Het nieuws over het verscherpt toezicht bij VTGZ slaat in als een bom in de regio en bij de deelnemende gemeenten. In de daaropvolgende

26. Brief van de Inspectie voor de Gezondheidszorg en de Inspectie Jeugdzorg van 28 april 2016. 
maanden komen alle betrokken actoren in een verhoogde staat van paraatheid. Het DB en $\mathrm{AB}$ komen in deze periode vaker bijeen, de raden worden vaker geïnformeerd, er vinden regionale informatiebijeenkomsten voor raadsleden plaats en in de gemeenteraden komt Veilig Thuis veel vaker aan de orde. Er komt een aanzienlijke informatiestroom, inclusief veel vertrouwelijke voortgangsinformatie, op gang in de richting van het $\mathrm{AB}$ en de gemeenteraden. Binnen de organisatie wordt met veel extra (gemeentelijk) geld, inzet en een interimmanager hard gewerkt aan oplossing van de problemen. Ondanks afname van de wachtlijsten besluiten de inspecties in oktober 2016 het verscherpt toezicht te verlengen in verband met de 'fragiele organisatieontwikkeling'. Uiteindelijk wordt in april 2017 naar aanleiding van de hertoets van stap 1 van het toezicht door de inspecties vastgesteld dat VTGZ zich voldoende heeft verbeterd en wordt het verscherpt toezicht opgeheven.

Conclusie: gebrekkige informatievoorziening en controle

In hun rapport van april $2018^{27}$ formuleren de rekenkamerkamer(commissie)s van Rijk van Nijmegen een aantal stevige conclusies ten aanzien van de voorbereiding van en de besluitvorming over Veilig Thuis.

Op het punt van de controle door gemeenteraden stelt het rapport dat het onderzoek laat zien dat problemen bij Veilig Thuis (en moederorganisatie GGD) pas gedeeld werden als er tegelijkertijd een oplossing kon worden voorgelegd, en dat die oplossingen bovendien een hoge mate van wensdenken lieten zien. Het gevolg hiervan was dat de gemeenteraden steeds (erg) laat en gebrekkig werden geïnformeerd. Zij konden in feite niets anders doen dan instemmen met de geboden oplossingen en de voorgestelde begrotingswijzigingen. Dit mechanisme werd versterkt door een uiterst zwakke kaderstelling: doordat er vooraf nauwelijks afspraken waren gemaakt tussen gemeenteraden en colleges over te behalen doelstellingen van Veilig Thuis en de rapportage daarover (frequentie, indicatoren), wisten de raden in feite niet waar ze naar moesten vragen. Dit alles betekent dat zij hun controlerende rol niet goed hebben kunnen vervullen.

\section{Democratische controle versus toezicht op het lokaal bestuur}

Het genoemde onderzoek naar Veilig Thuis in de Nijmeegse regio is een goede illustratie van de eerdergenoemde onvrede en zorg bij gemeenteraden over de sturings- en controlemogelijkheden van gemeentelijke samenwerkingsverbanden. De casus laat zien dat het in de praktijk heel moeilijk zo niet onmogelijk is voor raadsleden in de deelnemende gemeenten om de uitvoering van deze belangrijke gemeentelijke taak daadwerkelijk te controleren. ${ }^{28}$ De afstand tussen de uitvoerende organisatie en de gemeenteraden van de (zestien) deelnemende gemeenten is groot, zowel fysiek als in termen van de getrapte sturings- en informatierelatie: die loopt van de organisatie van de verbonden partij via het $\mathrm{DB}$, het $\mathrm{AB}$, de colleges van $\mathrm{B} \& \mathrm{~W}^{29}$ naar de gemeenteraden. Tegen de tijd dat de gemeenteraden worden geïnformeerd, zijn er maanden verstreken. De raden worden met name geïnformeerd op momenten dat hun instemming nodig is voor de toekenning van extra middelen.

De casus laat ook zien hoe belangrijk de rol van de inspecties is geweest bij het informeren van de gemeenteraden in de Nijmeegse regio over de problemen bij Veilig Thuis, en vervolgens het versterken van de (financiële) inspanningen om de problemen in de uitvoering aan te pakken. Als de inspecties in 2015 en 2016 geen intensief toezicht hadden uitgeoefend op de nieuwgevormde regionale Veilig Thuis-organisaties, wanneer waren het $\mathrm{AB}$ van de GGD c.q. de portefeuillehouders en colleges van de deelnemende gemeenten er dan achter gekomen dat de problemen in de Veilig Thuis-organisatie zo groot waren? En wanneer zouden de gemeenteraden daarover zijn geïformeerd? Die vragen kunnen vanzelfsprekend niet worden beantwoord, maar gesteld kan worden dat de gemeenteraden in deze casus ter aanvulling van hun eigen informatievoorziening de inspecties, de door hen verzamelde informatie en de beoordeling van de kwaliteit en de organisatie van de uitvoering hard nodig hadden. Dit is opvallend, omdat de wetgever dit uitdrukkelijk andersom had bedacht bij de decentralisatie van de taken in het sociaal domein en ook bij de hervorming van het interbestuurlijk toezicht enkele jaren eerder: het interbestuurlijk toezicht moest nadrukkelijk aanvullend zijn op de democratische controle door de gemeenteraden, soms ook horizontaal toezicht
27. Grip krijgen op Veilig Thuis (april 2018), zie: https://gemeentebestuur. beuningen.nl/gemeentebestuur/rekenkamer/.
28. Met - nogmaals - de kanttekening dat de gemeenteraden op grond van de Wet gemeenschappelijke regelingen een indirecte of beperkte controlerende rol hebben.

29. Strikt juridisch beschouwd zijn de colleges geen schakel, omdat zij de bevoegdheid voor Veilig Thuis aan het bestuur van de gemeenschappelijke regeling hebben overgedragen. In het wetsvoorstel democratisering samenwerkingsverbanden wordt het college als schakel uit deze keten gehaald, door het $A B$ (in art. $17 \mathrm{Wgr}$ ) een actieve informatieplicht jegens de gemeenteraden te geven. 
genoemd. ${ }^{30}$ Ik kom hier straks nog uitgebreider op terug.

De constatering dat het toezicht op Veilig Thuis van belang is geweest voor het controlerende werk van de gemeenteraden in deze casus, roept de vraag op of en in welke mate gemeenteraden bij de controle van samenwerkingsverbanden gebruik kunnen maken van het werk van rijksinspecties en de provinciale toezichthouder. ${ }^{31}$ Welke bronnen zijn er in dit verband eigenlijk beschikbaar? Hieronder presenteer ik een eerste beperkte verkenning van het interbestuurlijk toezicht op gemeentelijke samenwerkingsverbanden. ${ }^{32}$ De verkenning is beperkt tot vier van de grote gemeenschappelijke regelingen waar Nederlandse gemeenten aan deelnemen. Op zoek naar concrete voorbeelden wordt af en toe ingezoomd op de regio Rijk van Nijmegen en de gemeente Beuningen. ${ }^{33}$

\section{Interbestuurlijk toezicht op gemeentelijke} samenwerkingsverbanden: een verkenning

\section{Sociaal domein: $G G D$}

In het sociaal domein stuiten we allereerst op de GGD, het grote, wettelijke verplichte samenwerkingsverband dat taken uitvoert op basis van de Wet publieke gezondheid (Wpg). Toezicht op de naleving van die wet is bij de Inspectie Gezondheidszorg en Feugd (IGJ) belegd. Uit het Werkplan voor 2019 en het Jaarbeeld 2017 is af te leiden dat IGJ toezicht houdt op de GGD'en (en GHOR) en de kwaliteit van hun werk, maar het is onduidelijk naar welke aspecten wordt gekeken, hoe vaak dit plaatsvindt en of/hoe de resultaten worden gepubliceerd. Daarnaast valt de Veilig Thuis-organisatie - die in sommige regio's bij de GGD is ondergebracht, maar niet overal blijkbaar onder de aanbieders in het jeugddomein, en daarmee ook onder het toezicht door IGJ. Uit de jaarstukken van de GGD Gelderland Zuid valt niets op te maken over toezicht door de inspectie. $^{34}$

Een scan van de beschikbare openbare rapporten van IGJ over de GGD'en levert rapporten op met grote relevantie voor gemeenteraden. Zo bood IGJ eind 2016 een uitgebreide brief aan de minister van Volksgezondheid, Welzijn en Sport

30. Zie de conclusies over de beleidstheorie achter de hervorming, in: Winter, Munneke, Geertsema, Krol, De Ridder, Struiksma en Veen 2017, p. 37-39.

31. Daarnaast is het goed om erop te wijzen dat in het sociaal domein horizontaal en verticaal toezicht naast elkaar functioneren. Op grond van de Participatiewet en de Wet maatschappelijke ondersteuning (Wmo 2015) hebben gemeenten een wettelijke plicht om eigen (of op regionaal niveau gezamenlijke) toezichthouders aan te wijzen. Deze blijft in dit artikel buiten beschouwing.

32. Gebruikmakend van de voorbereiding ten behoeve van de rekenkamerbrief Gemeenteraad \& verbonden partijen, Beuningen, november 2019.

33. De auteur is sinds 2013 rekenkamerdirecteur van de gemeente Beuningen, onderdeel van de regio Rijk van Nijmegen.

34. GGD Gelderland Zuid, Begroting 2020 en Jaarrekening en -verslag 2018.
(VWS) aan, die had gevraagd om zicht op 'de uitoefening van de taken van de GGD'en' ${ }^{35} \mathrm{De}$ brief, die deels een benchmark van de GGD'en bevat, is onder meer gebaseerd op bestudering van documenten en kwalitatief onderzoek onder de directeuren publieke gezondheid (DPG) van de GGD'en. In dezelfde tijd publiceerde IGJ ook onderzoek naar de taakuitoefening door tien niet nader genoemde Jeugdgezondheidsorganisaties (JGZ) waarvan er negen bij de GGD zijn ondergebracht, ${ }^{36}$ en naar de manier waarop GGD'en infectieziektebestrijding aanpakken. ${ }^{37}$ Daarnaast zijn er veel rapporten over de regionale Veilig Thuis-organisaties te vinden op de IGJwebsite.

\section{Sociaal domein: Werkbedrijf}

Het tweede grote, intergemeentelijke samenwerkingsverband in het sociaal domein is het Werkbedrijf. Gemeenten werken in 35 wettelijk verplichte arbeidsmarktregio's samen in de Werkbedrijven voor de werkgeversdienstverlening, registreren samen met het Uitvoeringsinstituut Werknemersverzekeringen (UWV) werkzoekenden en vacatures en moeten op die schaal met het UWV en sociale partners ook zorgen voor voldoende banen voor mensen met een beperking. De Werkbedrijven voeren wettelijke taken uit gebaseerd op de Participatiewet, de Wet structuur uitvoeringsorganisatie werk en inkomen (Wet SUWI) en de Wet banenafspraak en quotum arbeidsbeperkten. De Inspectie $S Z W$ zegt in haar Meerjarenplan 2019-2022 over het programma 'Toezicht SUWI en sociaal domein' dat het toezicht naast uitkeringsverstrekking door gemeenten ook 'de uitvoering van de decentralisaties door gemeenten' betreft. 'Dit wordt gedaan door deelname aan Toezicht Sociaal Domein, waarin verschillende rijksinspecties samenwerken. Hun activiteiten richten zich op SUWItaken in samenhang met zorg-, onderwijs- en andere decentrale taken. Tot slot houdt het programma zich op verzoek van de minister en/of de staatssecretaris bezig met het uitvoeren van onderzoeken op het terrein van werk en inkomen.'

Een scan van de openbare rapporten van de Inspectie $\mathrm{SZW}^{38}$ laat zien dat er op diverse onderwerpen onderzoek in en naar gemeenten wordt gedaan, ook op onderwerpen die zijn belegd bij c.q. raken aan de regionale Werkbedrijven. Een in dit opzicht zeer relevant voorbeeld is onderzoek naar de begeleiding van jonge-

35. IGJ, Brief aan Minister over stand van zaken GGD'en, 31 oktober 2016.

36. IGJ, Tussenrapportage Jeugdgezondheidszorg Toezicht 2016-2017 periode 1, Den Haag 2016. De tien onderzochte organisaties dekken samen 139 gemeenten af, maar uit het rapport blijkt niet welke organisaties zijn onderzocht.

37. IGJ, Vervolgonderzoek Infectieziektebestrijding, Den Haag 2016.

38. Zoals te vinden op de website. 
ren met een arbeidsbeperking naar duurzaam werk (2018), waarbij de inspectie ook heeft gekeken naar de wijze waarop binnen arbeidsmarktregio's wordt samengewerkt bij het aan het werk helpen van jongeren met een arbeidsbeperking. ${ }^{39}$ Een ander voorbeeld is inventariserend onderzoek in 2015 en 2016 naar het aanbieden van beschut werk door gemeenten, ${ }^{40}$ een onderzoek dat laat zien dat een kwart van de Nederlandse gemeenten geen beschut werk aan zijn inwoners aanbiedt. ${ }^{41}$ Onderzoek naar de algemene taakuitoefening door regionale werkbedrijven is niet aangetroffen.

De Inspectie SZW werkt daarnaast met andere rijksinspecties samen in het Toezicht Sociaal Domein. ${ }^{42}$ De samenwerkende inspecties doen onderzoek naar diverse onderwerpen in gemeenten. Het betreft ook onderzoek dat raakt aan het takenpakket van de Werkbedrijven. Een voorbeeld is onderzoek in 2018 en 2019 in enkele gemeenten naar de participatie van jongvolwassenen zonder startkwalificatie en de wijze waarop de diverse partijen, waaronder gemeenten, samenwerken om ze te leiden naar werk of andere vormen van participatie. ${ }^{43}$

\section{Ruimtelijk domein: Omgevingsdienst}

In het ruimtelijk domein zijn gemeenten verplicht samen te werken in Omgevingsdiensten, die de gemeentelijke (en provinciale) taken op het gebied van vergunningverlening, toezicht en handhaving (VTH) in het kader van het omgevingsrecht uitvoeren. De provincie is de interbestuurlijk toezichthouder voor gemeenten en hun medebewindstaken, en de provincies hebben ervoor gekozen het interbestuurlijk toezicht te beperken tot dezelfde vijf of zes toezichtdomeinen, ${ }^{44}$ waaronder het omgevingsrecht c.q. de Wet algemene bepalingen omgevingsrecht (Wabo). De Inspectie Leefomgeving en Transport (ILT) werkt wel samen met de Omgevingsdiensten in het toezicht op bedrijven en instellingen, maar oefent geen toezicht uit op de Omgevingsdiensten. ${ }^{45}$

In het kader van deze verkenning is niet onderzocht hoe alle provincies hun toezichtrol op het terrein van het omgevingsrecht concreet invullen. Voor de casus van de gemeente Beuningen kan worden vastgesteld dat de provincie Gelderland zich tevreden stelt met een tijdige aanlevering van het jaarlijkse uitvoeringsprogramma VTH en evaluatieverslag VTH van de gemeente, en het opvolgen van eventuele klachten en meldingen. ${ }^{46}$ Toezicht op de taakuitoefening door de Omgevingsdienst maakt geen deel uit van het interbestuurlijk toezicht door de provincie Gelderland. ${ }^{47}$ Ook elders in het land lijkt dit niet gebruikelijk. ${ }^{48}$ Een dergelijke rol zou ook lastig zijn, gezien het feit dat de provincies ten aanzien van de Omgevingsdienst een 'dubbele pet ${ }^{\prime 49}$ op hebben: ze zijn immers ook deelnemer en lid van het Algemeen bestuur van de Omgevingsdienst.

\section{Veiligheidsregio}

Gemeenten werken verplicht samen in een Veiligheidsregio. De 25 Veiligheidsregio's voeren, op grond van de Wet veiligheidsregio's uit 2010, de gemeentelijke taken uit op het gebied van de brandweerzorg, geneeskundige hulpverlening en de voorbereiding en coördinatie op het gebied van rampenbestrijding en crisisbeheersing.

\section{De Inspectie Fustitie en Veiligheid (JenV) oefent} toezicht uit op de Veiligheidsregio voor de taken brandweerzorg, rampenbestrijding en crisisbeheersing. De Inspectie JenV onderzoekt eenmaal per drie jaar de Veiligheidsregio's voor wat betreft rampenbestrijding en crisisbeheersing, en bundelt de bevindingen in de 'Staat van de Rampenbestrijding', een openbaar beschikbaar rapport bestaande uit een overzichtsdeel en 25 zogenoemde regiobeelden per Veiligheidsregio. ${ }^{50}$ Ook voor de brandweer is er in 2018 een dergelijk rapport verschenen: een overzichtsdeel plus 25 regiorapporten. ${ }^{51}$ De inspectie doet ook onderzoek naar incidenten. De Inspectie Gezondheidszorg en Feugd oefent toezicht uit op de ambulancezorg (Regionale Ambulance Voorziening), een belangrijk onderdeel van het takenpakket van de Veiligheidsregio's. IGJ maakt daarvoor gebruik van meldingen en toetst aan de wet en diverse zogenoemde veldnormen.
39. Inspectie SZW, Aan het werk, voor hoe lang, Den Haag 2018.

40. Onderzoek Beschut werk, oktober 2015 en Vervolgonderzoek Beschut werk - stand van zaken, voorjaar 2016.

41. Gemeenten zijn daartoe niet verplicht, voor alle duidelijkheid.

42. Zie voor meer informatie: www.toezichtsociaaldomein.nl.

43. Toezicht Sociaal Domein, Participatie zonder startkwalificatie, Rapporten, infographics en video, 2018 en 2019, zie: www. toezichtsociaaldomein. $\mathrm{nl} /$ onderzoeken-en-instrumenten/p/participatiezonder-startkwalificatie.

44. Archief- en informatiebeheer, huisvesting van statushouders, Wabo (omgevingsrecht), ruimtelijke ordening, monumenten en archeologie en gemeentefinanciën (Winter, Munneke, Geertsema, Krol, De Ridder, Struiksma en Veen 2017, p. 54)

45. Inspectie Leefomgeving en Transport, Jaarverslag 2018, Den Haag 2019.
46. Provincie Gelderland, Beoordeling Interbestuurlijk toezicht, Brief aan het college van de gemeente Beuningen, oktober 2017

47. De provincie neemt wel de gemeenschappelijke regelingen mee bij het financieel toezicht en het archieftoezicht (Provincie Gelderland, Uitvoeringsprogramma Interbestuurlijk toezicht 2016-2019).

48. Telefonisch interview.

49. D.J. Elzinga, R.J.M.H. de Greef en A.J. Munneke, Omgevingsdiensten onder de bestuurlijk-juridische loep. Het wetsvoorstel 'verbetering vergunningverlening, toezicht en handhaving' in het licht van de Wet gemeenschappelijke regelingen en de Wet revitalisering generiek toezicht, Groningen: Universiteit Groningen 2014, p. 24.

50. Inspectie JenV, Staat van de rampenbestrijding 2016, Den Haag 2016.

51. Inspectie JenV, Inrichting repressieve brandweerzorg, Den Haag 2018. 
De verkenning van het interbestuurlijk toezicht op de genoemde vier gemeenschappelijke regelingen laat zien dat de resultaten van het werk van de toezichthouders voor gemeenteraden zonder meer bruikbaar zouden kunnen zijn. Dat is in lijn met de ervaringen in de beschreven casus van Veilig Thuis in Gelderland-Zuid. De inspecties en de provincies (in hun rol als toezichthouder) verzamelen relevante informatie over de taakuitoefening door de samenwerkingsverbanden en beoordelen deze ook in de rapportages. Deze rapporten bieden de gemeenteraden niet alleen de mogelijkheid tot (aanvullend) inzicht in de taakuitoefening door hun eigen gemeenschappelijke regelingen, maar stellen de raadsleden soms ook in staat een vergelijking te maken met de manier waarop het elders in het land gaat. Raadsleden kunnen bijvoorbeeld een antwoord krijgen op de vraag: hoe doet onze Veiligheidsregio het qua rampenbestrijding, en doet zij het beter of slechter dan andere Veiligheidsregio's op de diverse aspecten van het takenpakket? Dergelijke antwoorden kunnen aanleiding zijn voor nadere controlerende activiteiten door raadsleden, zoals het stellen van schriftelijke of mondelinge vragen aan de portefeuillehouder of het agenderen van het onderwerp voor bijvoorbeeld rekenkameronderzoek.

\section{Gebruikmaken van toezicht op} samenwerkingsverbanden: barrières voor gemeenteraden

Het is op basis van de casus en de gepresenteerde beperkte verkenning niet mogelijk conclusies te trekken over de mate waarin Nederlandse gemeenteraden in de praktijk daadwerkelijk gebruikmaken van de rapporten en oordelen van de inspecties en de provinciale toezichthouder over gemeenschappelijke regelingen. Bij de evaluatie van de Wet revitalisering generiek toezicht in 2017 stelden de onderzoekers vast dat de gemeenteraden in de zes onderzochte gemeenten niet of nauwelijks gebruikmaakten van de oordelen van de provinciale toezichthouder over het functioneren van hun gemeente op de provinciale toezichtdomeinen. ${ }^{52}$ Er lijkt op zich geen reden om aan te nemen dat dit voor de gemeenschappelijke regelingen anders ligt.

Bij het uitvoeren van de verkenning werd echter duidelijk dat gemeenteraden soms helemaal niet op de hoogte (kunnen) zijn van het toezicht door provincie en Rijksinspecties. Er zijn diverse oorzaken voor deze onbekendheid:

\section{De gemeenschappelijke regelingen maken in hun jaarstukken geen melding van toezicht door provincie of inspecties}

In de regio Rijk van Nijmegen makt geen van de gemeenschappelijke regelingen die in de verkenning zijn

52. Winter, Munneke, Geertsema, Krol, De Ridder, Struiksma en Veen 2017, p. 63-67. meegenomen in haar jaarstukken melding van toezicht door Rijksinspecties of de provincie, laat staan van de resultaten (oordelen) ervan. Een enkele keer wordt wel van samenwerking met een rijksinspectie gerept, bijvoorbeeld bij de vormgeving van het eigen WMO-toezicht door de GGD. ${ }^{53}$

De toezichthouders communiceren hun oordelen niet rechtstreeks met de gemeenteraden

In geen van de gevallen zoals beschreven in de verkenning sturen toezichthouders hun rapporten over gemeenschappelijke regelingen rechtstreeks aan de gemeenteraden van de deelnemende gemeenten, ondanks het feit dat de (provinciale) toezichthouders in hun visie- en programmeringsdocumenten graag het belang van de gemeenteraden als eerste en voornaamste controleur van de gemeentebesturen benadrukken. ${ }^{54}$ Een enkele provincie stelt zelfs dat het interbestuurlijk toezicht eraan moet 'bijdragen dat de gemeenteraden en algemene besturen, als vertegenwoordigers van de burgers, op basis van begrijpelijke informatie weloverwogen uitspraken kunnen doen over de taakuitvoering door hun organisatie (horizontale controle)'. ${ }^{55}$ Ook de regering benadrukt in diverse recente wetsvoorstellen (onder meer de Wet revitalisering generiek toezicht en de Wmo 2015) dat moet worden uitgegaan van vertrouwen in de horizontale verantwoordingsmechanismen op lokaal niveau. ${ }^{56}$ Uit de verkenning kan niet worden afgeleid of inspecties en provincies hun rapporten wel standaard toesturen aan de Algemene besturen van de gemeenschappelijke regelingen, bestaande uit de vertegenwoordigers van de gemeentebesturen. De inspecties die Veilig Thuis Gelderland Zuid in 2016 onder verscherpt toezicht stelden, deden dat in elk geval niet. ${ }^{57}$

\section{De toezichthouders zijn niet altijd transparant over het toezicht (onderzoek) dat zij uitvoeren}

In het kader van de verkenning is steekproefsgewijs gekeken of de onderzoeken van de toezichthouders en de uitkomsten daarvan openbaar zijn en beschikbaar voor gemeenteraden. Wat opvalt, is dat hierin aanzienlijke verschillen bestaan tussen met name de verschillende Rijksinspecties.

Zo specificeert de Inspectie Gezondheidszorg en Jeugd in haar brief uit 2016 over de uitvoering van taken door de GGD'en ${ }^{58}$ niet op welke GGD'en de constateringen en conclusies in de brief betrekking hebben. Dat twee ervan achterblijven in het integraal werken, of dat ze 'niet allemaal' formatie voor milieuspecialisten hebben, zijn uitspraken waar gemeenteraden (en colleges en $\mathrm{AB}$ )

53. GGD Gelderland Zuid, Jaarverslag 2018, p. 28-29.

54. Zie voor een beschrijving hiervan: Winter, Munneke, Geertsema, Krol, De Ridder, Struiksma en Veen 2017, p. 63-67.

55. Provincie Brabant in het Beleidskader Interbestuurlijk toezicht 2016-2019 (Winter, Munneke, Geertsema, Krol, De Ridder, Struiksma en Veen 2017, p. 58).

56. Zie voor een beschrijving hiervan: Winter, Munneke, Geertsema, Krol, De Ridder, Struiksma en Veen 2017, p. 37-40 en 99.

57. Zij deden dat per brief aan de directeur in $\mathrm{cc}$ aan de voorzitter van het Dagelijks bestuur van de GGD, en meldden dat de brief met beoordeling op de website van de inspecties openbaar zou worden gemaakt.

58. IGJ, Brief aan Minister over stand van zaken GGD'en, 31 oktober 2016. 
niets aan hebben. De brief, gebaseerd op 'verkennend kwalitatief onderzoek onder alle Directeuren Publieke Gezondheidszorg (DPG)', vermijdt elke herleidbaarheid naar de specifieke GGD'en. De brief bevat overigens veel holle frasen en betekenisloze uitspraken, waar noch gemeenten noch de minister en Tweede Kamer iets mee kunnen: de organisaties 'werken aan vergelijkbaarheid', hun sturingsinformatie is 'in ontwikkeling' en de samenwerking 'is sterk verbeterd'. En dat terwijl de inspectie zegt dat doel was om 'een beeld [te] vormen van de kwaliteit van de aansturing en van de borging van de uitvoering van de vier pijlers'. ${ }^{59}$ Ook in de rapporten van IGJ over de Jeugdgezondheidsdiensten en over de infectieziektebestrijding uit $2016^{60}$ wordt steeds vermeden om concrete uitspraken over specifieke GGD'en te doen. Het rapport over de tien Jeugdgezondheidsdiensten benoemt zelfs niet eens welke tien organisaties in het onderzoek zijn betrokken.

Eenzelfde opvallende praktijk is te zien in de rapporten van de Inspectie SZW. De Inspectie SZW doet met grote regelmaat onderzoek in en naar gemeenten (al dan niet samenwerkend in gemeenschappelijke regelingen zoals het regionale Werkbedrijf), zonder in het rapport en de onderzoeksverantwoording te specificeren in welke gemeenten onderzoek is gedaan. Zo besteedt het eerdergenoemde onderzoek naar de begeleiding van jongeren met een arbeidsbeperking naar duurzaam werk aandacht aan de wijze waarop door gemeenten en het UWV binnen arbeidsmarktregio's wordt samengewerkt bij de ondersteuning aan deze jongeren. Daarbij gaat blijkens het rapport wel het een en ander mis. Maar om welke veertien gemeenten het gaat, is op basis van het rapport niet te achterhalen. Een tweede voorbeeld is een onderzoek naar de gemeentelijke dienstverlening aan gezinnen met multiproblematiek en aan dak- en thuislozen. ${ }^{61}$ In de uitgebreide onderzoeksverantwoording ${ }^{62}$ wordt met geen woord gerept over welke drie grote gemeenten concreet zijn onderzocht.

Dit gebrek aan transparantie heeft ongetwijfeld te maken met de opdracht van de Inspectie SZW tot 'stelseltoezicht' op het gebied van werk en inkomen. ${ }^{63}$ In het meest recente Jaarverslag 2018 gaat de inspectie uitgebreid in op deze specifieke vorm van toezicht, die op 'het stelsel als geheel' is gericht, en niet in eerste instantie op de specifieke organisaties - in dit geval dus gemeenten - waar het onderzoek wordt uitgevoerd. ${ }^{64}$ Zonder hier de interessante maar ingewikkelde discussie over de betekenis en de afbakening van stelselverant-

59. IGJ, Brief aan Minister over stand van zaken GGD'en, 31 oktober 2016 , p. 2.

60. IGJ, Tussenrapportage Jeugdgezondheidszorg Toezicht 2016-2017 periode 1, Den Haag 2016; IGJ, Vervolgonderzoek Infectieziektebestrijding, Den Haag 2016.

61. Inspectie SZW, Werk en Inkomen als partner in integrale dienstverlening: een moeizame relatie, Den Haag 2017.

62. Inspectie SZW 2017, Bijlage 2, p. 55-62.

63. Zo wordt desgevraagd (per e-mail in september 2019) bevestigd door de Inspectie SZW voor wat betreft het onderzoek uit 2017.

64. Inspectie SZW, Jaarverslag 2018, Den Haag, p. 66-71. woordelijkheid en -toezicht ${ }^{65}$ te willen aangaan, moet met nadruk worden gewezen op de onwenselijke effecten van de keuze van de Inspectie SZW om geen duidelijkheid te verschaffen over de onderzochte gemeenten. De gemeenteraden van deze gemeenten als eerstverantwoordelijke controleur van het gemeentebestuur wordt op die manier belangrijke informatie over het functioneren van hun gemeente onthouden. De inspectie is een van de weinige partijen - een andere is de lokale rekenkamer(commissie) - die in gemeenten onafhankelijk en diepgaand onderzoek doet naar de feitelijke uitvoering van belangrijke gemeentelijke taken. Het is een serieus probleem dat het voornaamste democratische controleorgaan niet van de bevindingen op de hoogte wordt gebracht. ${ }^{66}$ De ene controleur laat de andere hier in de kou staan, zou je kunnen concluderen. Er is hier zelfs mogelijk sprake van een serieus staatsrechtelijk probleem: de inspectie legt blijkens haar rapporten de bevindingen van haar onderzoek in gemeenten ter verificatie voor aan de betrokken gemeenten, dat wil zeggen het gemeentebestuur. Dat betekent dat de colleges beschikken over belangrijke informatie over het functioneren van de gemeente. De actieve informatieplicht, zoals vastgelegd in de Gemeentewet, ${ }^{67}$ verplicht het college alle informatie ter beschikking te stellen aan de gemeenteraad die deze voor de uitoefening van zijn taak nodig heeft. Het ligt voor de hand dat dit ook de inspectiebevindingen betreft. Maar het heeft er dus alle schijn van dat de bevindingen de gemeenteraden niet bereiken. De samenwerkende inspecties in Toezicht Sociaal Domein zijn in hun openbare rapporten wel transparant over de gemeenten waar zij onderzoek doen. De deelrapporten met bevindingen uit de individuele gemeenten worden ook gepubliceerd op de website. Ook de Inspectie Justitie en Veiligheid publiceert de landelijke Staat van de rampenbestrijding inclusief de deelrapporten over de 25 Veiligheidsregio's op haar website.

Voor de provinciale toezichthouders is niet onderzocht of de bevindingen en oordelen in het kader van het interbestuurlijk toezicht de gemeenteraden bereiken. Er zijn provincies die hun toezichtrapporten enkel aan de colleges toesturen. ${ }^{68}$ Uit de casestudies (zes gemeenten verspreid over drie provincies) die onderdeel waren van de evaluatie van de Wet revitalisering generiek toezicht uit 2017 blijkt nergens dat de colleges hun raad niet informeren over de resultaten van het provinciale toezicht. $^{69}$

65. Raad van State, En nu verder! Vierde periodieke beschouwing over interbestuurlijke verhoudingen na de decentralisaties in het sociale en fysieke domein, Den Haag 2016, p. 33-39; Boogaard en Van Emmerik 2018, p. $134-165$

66. Theoretisch gezien zou het kunnen dat de colleges van de onderzochte gemeenten hun raad op de hoogte stellen van de (concept)bevindingen van de inspectie. Maar omdat we niet weten om welke gemeenten het gaat, kunnen we dit niet controleren.

67. Art. 169 lid 2 Gemeentewet voor het college en art. 180 lid 2 Gemeentewet voor de burgemeester.

68. De provincie Brabant heeft hiertoe enkele jaren geleden besloten.

69. Winter, Munneke, Geertsema, Krol, De Ridder, Struiksma en Veen 2017, p. 63-67. 
De gemeenteraden ontvangen van hun college van B\&W niet alle relevante rapporten en oordelen van de toezichthouders

In het kader van de verkenning is steekproefsgewijs gekeken of relevante landelijke rapporten en rapporten of oordelen over de betreffende gemeenschappelijke regelingen altijd aan de gemeenteraad worden gestuurd door het college van B\&W. Uit de steekproef blijkt dat dit niet altijd gebeurt. Dit geldt bijvoorbeeld voor een landelijk rapport van Toezicht Sociaal Domein (TSD) over jeugdzorg met zes deelrapporten over zes onderzochte gemeenten: ${ }^{70}$ in twee van de zes gemeenten is het deelrapport over de eigen gemeente door het college van $\mathrm{B} \& \mathrm{~W}$ niet aangeboden aan de gemeenteraad. ${ }^{71}$ De deelrapporten staan overigens wel op de website van TSD. Het is op basis van deze beknopte verkenning en steekproef echter niet mogelijk om vast te stellen hoe vaak dit gebeurt. Bovendien is niet altijd duidelijk of de portefeuillehouders c.q. colleges zelf wel over de rapporten beschikken. Maar vastgesteld kan in ieder geval worden dat sommige relevante rapporten over gemeenschappelijke regelingen de gemeenteraden van de deelnemende gemeenten niet bereiken. Waar die rapporten 'blijven steken' - is dat bij de inspecties of provinciale toezichthouder, bij het bureau van de gemeenschappelijke regeling, bij het $\mathrm{DB}$, bij het $\mathrm{AB}$, bij de portefeuillehouder of bij het college van $\mathrm{B} \& \mathrm{~W}$ - kan niet worden vastgesteld. Dit is een praktijk die nader moet worden onderzocht.

\section{Gemeenteraden zijn geen (serieuze) gesprekspartner van de toezichthouders}

De wereld van de rijksinspecties en die van het lokaal bestuur zijn tamelijk gescheiden werelden, zo blijkt. De nieuwe Jeugdwet schrijft voor dat de Inspectie Gezondheidszorg en Jeugd rekening moet houden met 'de behoeften van gemeenten', ${ }^{72}$ en de inspecties hebben regelmatig overleg met de Vereniging van Nederlandse Gemeenten (VNG). Er zijn ook eerste contacten tussen de Inspectie SZW en de Nederlandse Vereniging van Rekenkamers en Rekenkamercommissies (NVRR), tot nu toe nog zonder resultaat. Maar uit de meerjarenvisies en -programma's van de inspecties blijkt nergens dat het belang en de behoeften van de gemeenteraad als controleur van het college belangrijk worden gevonden en zijn meegewogen. Dat wordt ook goed zichtbaar in de 'Agenda toekomst van het (interbestuurlijk) toezicht' uit 2018, gezamenlijk opgesteld door de rijksoverheid, IPO en VNG. Weliswaar wordt daarin meermalen het belang van horizontale verantwoording en checks and balances benadrukt, maar bestuurders en volksvertegenwoordi-

70. Toezicht Sociaal Domein, Signaleren van onveiligheid, Utrecht 2016 (zie: www.toezichtsociaaldomein.nl/onderzoeken-en-instrumenten/s/ signaleren-van-onveiligheid).

71. Vastgesteld op basis van onderzoek in het raadsinformatiesysteem op de gemeentelijke website en een telefonische check bij de raadsgriffie.

72. Art. 9.1 lid 5 Jeugdwet. gers worden in het stuk op één hoop gegooid. ${ }^{73}$ Dat zegt in zekere zin voldoende. Niet voor niets is er sinds enkele jaren ook een Nederlandse Vereniging voor Raadsleden, die zich ten doel stelt het belang van gemeenteraden en raadsleden in Den Haag te behartigen. Dat lijkt hard nodig.

\section{Conclusie en vervolgvragen}

Gemeenteraden worstelen met hun controlerende taak, zeker ten aanzien van de grote regionale samenwerkingsverbanden waar hun gemeente deel van uitmaakt. Toch is de democratische controle door gemeenteraden een cruciaal argument geweest bij alle decentralisaties van de afgelopen jaren, en bij de herinrichting van het interbestuurlijk toezicht in 2012: nieuwe taken konden aan gemeenten worden overgelaten en het interbestuurlijk toezicht kon worden vereenvoudigd, want gemeenteraden zouden daar controle op uitoefenen. Maar hoewel er weinig empirisch onderzoek is gedaan naar de controlepraktijk in het lokaal bestuur, wijst alles erop dat het moeizaam gaat. De kwaliteit en kwantiteit van de informatievoorziening over met name de prestaties en effectiviteit van deze organen is daarbij een belangrijk knelpunt.

Bij nadere beschouwing blijkt dat een belangrijke bron van informatie over die prestaties en effectiviteit nauwelijks wordt gebruikt door gemeenteraden. Rijksinspecties en de provincies in hun rol als interbestuurlijk toezichthouder doen regelmatig onderzoek naar de taakuitoefening door gemeenten en de door hen ingestelde gemeenschappelijke regelingen. Een eerste, beperkte verkenning laat zien dat diverse Rijksinspecties rapporten publiceren over de taakuitoefening door gemeenschappelijke regelingen die voor gemeenteraden uiterst bruikbaar zijn.

Het lijkt er echter op dat veel van deze rapporten en toezichtoordelen de gemeenteraden niet bereiken. In welke mate dit het geval is, en of er verschillen zijn tussen gemeenten, of tussen verschillende toezichtdomeinen, zijn zaken die nader onderzoek verdienen. Ook de vraag waardoor het probleem wordt veroorzaakt, moet daarbij nadrukkelijk aan de orde komen. Een voorzichtige conclusie op basis van de verkenning is dat de verklaring hiervoor in belangrijke mate ook bij de toezichthouders zelf moet worden gezocht. Die lijken niet erg gespitst op het belang van de gemeenteraden als eerste controleur van het gemeentebestuur, en communiceren niet met hen, noch over de resultaten, noch over de programmering van hun toezichtactiviteiten in het (boven)lokaal bestuur. Dit zou op korte termijn moeten veranderen, als we democratische controle van het lokaal bestuur serieus willen nemen.

73. VNG, IPO, Staatssecretaris van Financiën \& Minister van BZK, Agenda toekomst van het (interbestuurlijk) toezicht, Den Haag 2018, p. 4 (zie: www.rijksoverheid.nl/actueel/nieuws/2018/12/21/agenda-voorvernieuwd-interbestuurlijk-toezicht). 
De verkenning waarover in dit artikel is gerapporteerd, betreft de praktijk voor wat betreft vier belangrijke gemeenschappelijke regelingen in het lokaal bestuur. Juist bij gemeenschappelijke regelingen is de controlerende rol van gemeenteraden ook formeel gezien een beperkte. ${ }^{74}$ De vraag is natuurlijk of het geconstateerde probleem niet veel groter is. Er is geen enkele aanleiding om te denken dat het niet speelt bij de taken die gemeenten zelf uitvoeren, dat wil zeggen niet in samenwerkingsverbanden. Daarvan zijn vele voorbeelden te bedenken, bijvoorbeeld op het terrein van de bijstandsuitkeringen of de gemeentelijke toegang tot jeugdhulp. Dit moet zeker in het onderzoek worden meegenomen.

Tot slot: de rapporten die de afgelopen jaren aandacht hebben besteed aan het interbestuurlijk toezicht en de ontwikkelingen daarin sinds de decentralisaties, zijn een belangrijke bron van informatie voor dit artikel gebleken. De rapporten worden echter sterk gekleurd door een Haags perspectief, en kijken veelal naar de gemeente als één ongedeelde actor, zonder veel oog voor de onderlinge verhoudingen tussen de bestuursorganen. Als de positie van gemeenten aan de orde komt, hebben de Raad van State met zijn periodieke beschouwingen van de interbestuurlijke verhoudingen, en de evaluaties van de Wet revitalisering generiek toezicht (2017) en de Jeugdwet (2018) vooral andacht voor de vraag of de rijksoverheid (minister, departementen, inspecties) de ministeriële verantwoordelijkheid en stelselverantwoordelijkheid niet te veel oprekken en de autonomie van gemeenten niet aantasten. Maar als het perspectief van de lokale volksvertegenwoordiging en haar verantwoordelijkheid als controlerend orgaan centraal worden gesteld, zien we ineens dat eventuele aantasting van de gemeentelijke autonomie misschien niet het belangrijkste probleem is. De wetgever is er de afgelopen jaren bij de diverse decentralisaties van uitgegaan dat gemeentebesturen goed worden gecontroleerd, maar het zou verstandig zijn om te erkennen dat de gemeenteraden in hun rol als democratisch controleur van een toenemend aantal belangrijke taken op (boven)lokaal niveau veel betere ondersteuning verdienen. ${ }^{75} \mathrm{Het}$ interbestuurlijk toezicht en de afstemming met de democratische controle op lokaal niveau zou daarin veel nadrukkelijker moeten worden meegenomen. Partijen die hierin een rol kunnen spelen zijn de lokale rekenkamers en hun koepelorganisatie NVRR, de Vereniging van Griffiers en de Nederlandse Vereniging van Raadsleden. Zij kunnen in politiek Den Haag de belangen van de gemeenteraad in dit opzicht agenderen, en hun leden op lokaal niveau attenderen op het belang van de beschikbare toezichtrapporten. 